\title{
An Evaluation of Organisational Change and Its Impact On Staff Productivity (A Case Study of Frist Bank PIc in Gbagada Branch)
}

\author{
Adeyemo, F.S. \& Agboola, W. \\ Department of Business Administration \\ Caleb University \\ Imota, Lagos State, Nigeria \\ 1E-mail: feliciaadeyemo@yahoo.com
}

\begin{abstract}
This research evaluates organizational change and its impact on staff productivity using First Bank of Nigeria PLC Gbagada as a case study. It elucidates the concept of organizational change as an inevitable organizational process that is required to modify operations and organizational process. The research proffers an analysis of the concept of productivity and seeks to determine the impact of organizational change on staff productivity. Findings from the research showed that there are problems associated with ever constant changes in organizations and this impacts on productivity of staff Statistical analysis of gathered data also showed that staff productivity influences performance of the case study organization and that change is generally acceptable in First Bank plc.
\end{abstract}

Keyword: Evaluation, Organisational Change, Staff Productivity, Frist Bank PIc, Nigeria

Aims Research Journal Reference Format:

Adeyemo, F.S. \& Agboola, W. (2018): An Evaluation of Organisational Change and Its Impact On Staff Productivity (A Case Study of Frist Bank Plc in Gbagada Branch). Advances in Multidisciplinary Research Journal. Vol. 4. No. 4, Pp 73-84

Available online at www.aimsjournal.net

DOI - dx.doi.org/10.22624/AIMS/V4N4P7xb

\section{INTRODUCTION}

Today's business environment produces change in the workplace more suddenly and frequently than ever before. Mergers, acquisitions, new technology, restructuring downsizing and economic meltdown are all factors that contribute to a growing climate of uncertainty. The ability to adapt to changing work conditions is key for individual and organizational survival. Change will be ever present and learning to manage and lead change includes not only understanding human factors, but also skill to manage and lead change effectively (Pettigrew and Whipp, 1991). Change is the inevitable. It is the only element of human phenomenal that is constant. Organizational change occurs when a company makes a transition from its current state to some desired future state. Managing organizational change is the process of planning and implementing change in organizations in such a way as to minimize employee resistance and cost to the organization, while also maximizing the effectiveness of the change effort. Change is both inevitable and desirable for any progressive organization (Fajana, 2002).

Today's business environment requires companies to undergo changes almost constantly if they are to remain competitive. Factors such as globalization of markets and rapidly evolving technological force businesses to respond in order to survive. Such changes may be relatively minor as in the case of installing a new software programme or quite major as in the case of refocusing an overall marketing strategy. Organizations must change because their environments change, according to Thomas $\mathrm{S}$. Bateman and Carl P. Zeithaml in their book management: function and strategy. Today businesses are bombarded by incredibly high rates of change from a frustrating large number of sources. Inside pressures come from top managers and lower-level employees who push for change. Outside pressures come from changes in the legal, competitive, technological and economic environments. 
By acceptance of organizational change, we mean the employees readiness and willingness, support and commitment to the organizational ideals during the periods of significant internal and external shifts in the organization's structure. Managers must not rush in introducing a change. The process must be slow, steady and thorough (Fajana, 2002). Acceptance of change signifies the willingness of the affected parties to embrace and function in a newly established order and their commitment to effect and implement the changes. As underlined by scholars such as Pettigrew and Whipp (1991), Fajana (2002) and Armstrong (2004), for planned change to bear its desired outcomes, it must be introduced, implemented and managed in such a way that attracts and gains the commitment from the affected parties to drive the changes to achieve the desired goals and the existence of a common vision that change for the organization is necessary and inevitable.

Conceptually, the change process starts with an awareness of the need for change. An analysis of this situation and the factors that have created it leads to a diagnosis of their distinctive characteristics and an indication in which action needs to be taken. Change signifies the willingness of the affected parties to embrace and function in a newly established order and their commitment to effect and implement the changes (Armstrong, 2004). Effecting change can also be painful. When planning change, there is a tendency for people to think that it will be an entirely logical and linear process of growing from point $A$ to B, it is not like that at all. As described by Pettigrew and Whipp (1991), the implementation of change is an interactive, cumulative and reformulation in-use process. In order to manage change, it is first necessary to understand the types of change and why people resist change. It is important to bear in mind that while those wanting change need to be constant about ends, they have to be flexible about means. Bateman and Zeithaml (1990), identified four major areas of organizational change in strategy, technology, structure and people. All the four areas are related and companies often must institute changes in the other areas, when they attempt to change one area. The first area, strategy changes can take place on a large scale-large for example, when a company shifts its resources to enter a new line of business or on a small scale for example, when a company makes productivity improvements in order to reduce costs.

There are three basic stages for a company making a strategic change: realizing that the current strategy is no longer suitable for the company's situation, establishing a vision for the company's future direction and implementing the change and setting up new systems to support it. Technological changes are often introduced as components of larger strategic changes, although they sometimes take place on their own. An important aspect of changing technology is determining who in the organization will be threatened by the change. To be successful, a technology change must be incorporated into the company's overall systems and a management structure must be created to support it. Structural changes can also occur due to strategic changes as in the case where a company decides to acquire another business and must integrate it as well as due to operational changes or changes in managerial style. For example, a company that wished to implement more participative decision making might need to change its hierarchical structure.

People changes can become necessary due to other changes, or sometimes companies simply seek to change workers' attitudes and behaviors in order to increase their effectiveness. Attempting a strategic change, introducing a new technology and other changes in the work environment may affect people's attitudes (sometimes in a negative way) (Bateman and Zeithaml, 1990). But management frequently initiates programs with a conscious goal of directly and positively changing the people themselves. In any case, people changes can be the most difficult and important part of the overall change process. The science of organization development was created to deal with changing people on the job through techniques such as education and training, team building and career planning. Resistance to change: Resistance to change based on the existing theoretical and empirical study, the negative evaluation of and resistance to change may occur on account of a number of Factors. Bateman and Zeithaml (1990) outlined a number of common reasons that people tend to resist change. These include: inertia, or the tendency of people to become comfortable with the status quo, timing, as when change efforts are introduced at a time when workers are busy or have a bad relationship with management, surprise, because people's reflex is to resist when they must deal with a sudden, radical change or peer pressure, 
which may cause a group to resist due to anti- management feelings even if individual members do not oppose the change. Resistance can also grow out of people's perceptions of how the change will affect them personally.

They may resist because they fear that they will lose their jobs or their status, because they do not understand the purpose of the change, or simply because they have a different perspective on the change than management. Making a solid case for the change is critical for the change to have a lasting effect. The source of information about the change must be credible. Stroh's (2001-2002) study indicates that the participation of employee leads to more positive relationships with the organization and thus greater willingness to change. Therefore, the research intends to prefer an evaluation of organizational change and its impact on staff productivity.

\subsection{Statement of the Problem}

The business environment produces change in the workplace more suddenly and frequently than ever before. Mergers, acquisitions, new technology, restructuring downsizing and economic meltdown are all factors that contribute to a growing climate; of uncertainty. Organizational ability to adapt to changing work conditions is key for individual and organizational survival. Change will be ever present and learning to manage and lead change includes not only understanding human factors, but also, skill to manage and lead change effectively (Pettigrew and Whipp, 1991).

However, for change to produce its desired effect it must be accepted and embraced by the organizational employees; But this is not often the case. Most changes results in employee resistance of change in the organization; Thereby resulting in poor morale and productivity. Therefore, the problem confronting this research is to proffer an evaluation of organizational change and its impact on staff productivity with a case appraisal of First Bank plc, Gbagada Branch.

\subsection{Research Question}

The research questions that emanates from the foregoing are as follows:

What is the nature of organizational change

What is the process and methods of organizational change 3 What constitute staff productivity

What is the impact of change on staff productivity

What is the impact of change on staff productivity in First Bank plc, Gbagada Branch

\subsection{Objective of The Study}

1 To determine the nature of organizational change 2 To examine the nature of staff productivity

To ascertain the impact of change on organizational productivity

To determine the impact of change on staff productivity in First Bank plc, Gbagada Branch

\subsection{Significance of The Study}

The study shall focus on the essential factors necessary to effect change in the organization.

It shall determine the impact of change on organizational productivity. The study shall provide significant information on managing change to managers and organizations.

\subsection{Statement of The Hypothesis}

Ho Staff productivity in First Bank plc is low Hi Staff productivity in First Bank plc is high

Ho changes is not accepted in First Bank plc Hi change is accepted in First Bank plc

Ho The impact of change on staff productivity in First Bank plc is negative Hi The impact of change on staff productivity in First Bank plc is positive 


\section{LITERATURE REVIEW}

\subsection{Organizational Change}

The concept of the organizational change comes from the nature and environment of the organizations. Change basically means series of events which supports the process of development in organizations. (Kassim, Tahajuddin, Shahzad, Isa, \& Mat, 2010). Organizational change generally means rightsizing, new development and change in technologies, rescheduling operations and major partnerships. (McNamara, 2011). organizational change includes Mission changes, Strategic changes, Operational changes (including structural change), Technological changes, Changing the attitudes and behaviors of personnel, Counter resistance from different employees of companies and align them to strategic directions of the organization. In today's dynamic environment organizational change is indispensable for every organization to proceed and prosper in ever changing business environment.

A survey conducted by McKinsey on a five year data, 1536 companies were taken for this survey which generally meant for organizational change, the result of the survey shows that $38 \%$ organizations were succeeded in achieving high employee performance. (Isern \& Pung, 2007). Internal and external factors must be considered in the process of organizational change in order to alter their way of business for organizational growth. The goals of organizational change are multi-faceted however the major ones are improving the organization mergence, crisis intervention and to overcome day to day hauling competition. (Isern \& Pung, 2007). In this research paper, the impact of organizational change towards employee performance in banking sector of Pakistan is measured. According to the data collected from different sources, there are eight variables which are leadership, communication, employee development, tolerance to change, procedural justice, and finally employee performance.

In these variables there are five independent variables which are leadership, communication, employee development, tolerance to change, procedural justice, and one dependent variable that is employee performance. Employee Performance Employee performance is vital for the success of every organization and profitability in this dynamic environment. (Chien, 2004). Now a days organizations require such type of employees who contribute more than their job scope and far from goals expectations. Most of the organizations copping with contemporary challenges put more emphasis on employee performance. (Gruman\& Saks, 2011).

According to some authors, service firms like banking sector invests more on their work force in order to maintain long term relationship with them and to increase their performance along with job Satisfaction. (Karatepe, Uludag, Menevis, Hadzimehmedagic, \& Baddar, 2006). Downsizing, mergers, innovations and restructuring of the organizations usually decrease employee's performance. In additions to that, task, quantity and quality, changing location and time constraints radically affect the work life of employees. ( Tavakolia, 2010). Nowadays, many companies are facing current challenges and need to put more concentration on increasing employees' performance. Hence, to connect in valuable performance, managers need to let employees to have more power to design their jobs and roles. Thus, employees will find their jobs more fit between employees' needs, skills and values. (Gruman\& Saks, 2011). The deficiencies of employee performance will be overcome by effective leadership, communication, motivation, employee development, tolerance to change, procedural justice, and organizational culture.

\subsection{Leadership}

A leader is one whose behavior guides people towards their goal achievement. Leadership influences managers, employees of the organization and organization performance with goal achievement. (Stogdill, 1974). Different styles of the leader play a vital role towards enhancing employee's performance in order to achieve their goals. (Wang, Fan, Hsieh, \&Menefee, 2009). According to Appelbaum, Hebert; Leroux, (1999) two classical leadership styles emerge, one is characterized by a more directive, authoritarian style of management that focuses on the task and initiating structure. The other is characterized by sharing of information, participation, consultation, delegation and joint decision making focused on employee orientation and consideration. (Vecchio \& Appelbaum, 1995). 
An employee's autonomy and self-responsibility could be reduced by close control from their leader. If an employee feels to be competent and has willpower but managerial behaviors that can restrict their freedom such as observing them all the time or keep on checking their work performance could draw out psychological problems that could affect the performance of the employees and such reaction could bring poor job attitudes, minimum level of efforts by the employee or both. (Brehm, 1972).

The success of organizational change and employee performance depends mainly on leadership commitment and roles. The key to the success of these leaders depends on vision rather than analysis, on learning rather than on knowing because a leader has a strong communication of the vision because this is more important in today's leaders. (Wesley, 1996). A leader has the ability to influence their employees so that they can work efficiently and get the things done in order to achieve organizational goals. (Wang, Law, Hackett, Wang, \& Chen, 2005). The performance of the organization will increase if employees share their ideas and values with each other. A leader is one who can give rewards to his employees, motivate their employees towards task achievement, giving incentives; give moral support so that employees put more effort to their work. (Webb, 2007)

\subsection{Communication}

Communication is a process through which information, ideas and knowledge can be exchanged. There are many ways through which communication process can be delivered as writing, print or electronic media and through speech. It is a tool by which people can communicate with each other. With effective communication ideas and information can be conveyed. (Wanguri 1995). Organizational communication is defined as the method in which language is used as a tool to make different kind of societal structures, such as teams, relationships, and networks. (Eisenberg, Goodall, \&Trethewey, 2007). Organizational communication takes place in many forms which includes supervisor communication, communication climate, horizontal communication, media quality, organizational integration, organizational perspective, personal feedback, subordinate communication as well as top management Communication. (Wanguri 1995). Communication with workforce is essential in order to lessen the employees negative impact when changes done in the organization.

Management needs this strategy to win the trust of the employees through effective communication to enhance employee performance and employee's perception about management new styles and trustworthiness.(Nikandrou, Papalexandris, \& Bourantas, 2000).

When management changes organizational structure those employees who are career oriented put their extra efforts to groom themselves and make extra commitment to maintain organizational change efforts. (Rashid \& Zhao, 2010). Through effective communication managers of the organization can build strong relationship with peers and sub-ordinates. Those organizations whose has an open policy system encourage their employees to give inputs, share ideas so that organizational performance should be improved. (Dahlberg, 2007). Communication is more effective to influence the lower level employees because they are directly related to production of the organization and shows positive linkage between communication and productivity. Communication is most important in HR department because they make decisions regarding on hiring stage and performance. (Joseph \& Patricia, 1989).

\subsection{Employee Development}

The process of employee development plays a vital role in developing or let losing their employees through training and organizational development with the purpose of increasing their performance. The basic purpose of employee's development is to achieve those units which are human made with the intention of achieving human potential with the purpose of attaining organizational objectives and those skilled personnel are advocated of groups, organizational credibility and work Procedure. (Hassan, 2007). Employee development is necessary for every organization, when these activities are performed it indicates that organization wants to improve the performance of their employees. 
Nowadays organizations are investing much on employee development programs, the employees utilize their full skills, work hard and want to achieve organizational goals. This indicates that employee development programs indicate those employees who are willing to learn and when they show willingness to learn they show interest in the development activities, as a result, they are satisfied with their job which will ultimately lead to increase employee performance. (Elena, 2000).

When organizations invest on employee development sessions this will improve employee's skills, they have better career growth and, in this way, cultural, economic growth will be enhanced on the society level. (Champathes, 2006). Organizations such as banks, healthcare sectors find that sales personnel's training is necessary for the performance of a sales person. In the end the sum of benefits of training must be greater than the sum of costs. (Attia, Honeycutt, \&Attia, 2002).

\subsection{Procedural Justice}

Procedural justice means that all employees should be treated on equal footing, there should be no discrimination in job distribution procedures and employees perception how fairly they will be treated in their jobs skills and performance.(Aryee, Chen, \& Budhwar, 2004). Procedural justice is related to the organization outcome which can be associated with employee performance, Job satisfaction and organizational commitment. (Hon \& Lu, 2010). In this way employees are satisfied that their leaders are able to assist and guide them in their work efforts and assess them in a fairly manner. On the other hand procedural justice will lead the employees in cross functional teams to bring positive effect on their performance and improve team quality. Those teams who follow procedural justice have high level of work performance than those with low level procedural justice. (Hon \& Lu,2010).

\section{RESEARCH METHODOLOGY}

\subsection{Research Population}

Population is a set of data that characterize some phenomenon of interest. It is the collection of all objects in which data were obtained. In this study, population included all the 42 seniors and 18 intermediate staffs of the bank, both marketing and administrative staffs. The total number of staffs used in the sample were 60. A sample is a group of subjects selected from population of study for the purpose of drawing a sample. The research used random sampling technique in the selection of the sample size from the population.

\subsection{Sample Size and Sample Techniques}

A sample is a group of selected objects from a population of study for the purpose for which the sample has been drawn. The sample size is 60 .

\subsection{Method of Gathering Data}

Primary data are those original information collected by the researcher. They include personal interviewing method and questionnaire.Some respondents were not willing to answer some questions they consider delicate verbally, the preferred anonymity and therefore answered the questionnaire. Some of the respondents felt disturbed and uncomfortable by the presence of the researcher in their offices. In this research the researcher constructed a simple and straight forward questions from which he obtained the necessary data.

\section{Justification for the Method Used}

This technique was chosen because it gives all members of the population equal chance of being selected or represented. A sample size of $10 \%$ was derived from a population of 60 . So according to Roscoe rule of thumb. And $10 \%$ of 60 , therefore is $6 \%$. 


\section{DATA PRESENTATION, ANALYSIS AND INTERPRETATION}

This Section is devoted to the presentation, analysis and interpretation of the data gathered in the course of this study. The data are based on the number of copies of the questionnaire completed and returned by the respondents. The data are presented in tables. The chi-square test was used in the validation of hypotheses.

4.1 Data Presentation and Analysis

The data presented below were gathered during field work: BIO DATA OF RESPONDENTS

Table 1 Gender of respondents

\begin{tabular}{|c|c|c|}
\hline Valid & Frequency & Percent \\
\hline Male & 35 & 58.3 \\
\hline Female & 25 & 41.7 \\
\hline Total & 60 & 100 \\
\hline
\end{tabular}

Source: field survey, 2018.

Table 1 above shows the gender distribution of the respondents used for this study.

Out of the total number of 60 respondents, $35(58.3 \%)$ of the population are male while $25(41.7 \%)$ of the population are female.

Table 2: Age grade of the respondents

\begin{tabular}{|ll|l|}
\hline Valid & Frequency & Percent \\
\hline $15-20$ years & 8 & 13.3 \\
\hline $21-30$ years & 22 & 36.7 \\
\hline $31-40$ years & 25 & 41.7 \\
\hline $41-50$ years & 3 & 5 \\
\hline Above 50years & 2 & 3.3 \\
\hline Total & 60 & 100 \\
\hline
\end{tabular}

Source: field survey, 2018.

Table 2 above shows the age grade of the respondents used for this study.

Out of the total number of 60 respondents, 8 respondents $(13.3 \%)$ of the population are between 15 20 yrs.

22 respondents $(36.7 \%)$ of the population are between $21-30 y r s .25$ respondents $(41.7 \%)$ of the population are between $1-40 \mathrm{yrs} 2$ respondents $(3.3 \%)$ of the population are over $50 \mathrm{yrs}$.

Table 3: Educational Qualifications

\begin{tabular}{llll}
\hline Valid & Frequency & Percent \\
\hline WASSCE/SSCE/NECO & 20 & 33.3 \\
\hline OND/HND/BSC & 28 & 46.7 \\
\hline PGD/MSC/PHD & 2 & 3.3 \\
\hline OTHERS & 10 & 16.7 \\
\hline TOTAL & 60 & 100
\end{tabular}

Source: field survey, 2018. 
Table 3 shows the educational qualification of the respondents used for this study. 20 respondents (33.3\%) of the population are SSCE/GCE/WASSCE holders.

28 respondents $(46.7 \%)$ of the population are OND/HND/BSC holders. 2 respondents $(3.3 \%)$ of the population are PGD/MSC/PHD holders. 10 respondents $(16.7 \%)$ of the population have other type of certificates.

Table 4: Marital Status

\begin{tabular}{lll|}
\hline Valid & Frequency & Percent \\
\hline Single & 25 & 41.7 \\
\hline Married & 28 & 46.7 \\
\hline Divorced & 4 & 6.7 \\
\hline Widowed & 3 & 5 \\
\hline Total & 60 & 100
\end{tabular}

Source: field survey, 2018.

Table 4 above shows the marital status of the respondents used for this study. 25 respondents $(41.7 \%)$ of the population are single. 28 respondents $(46.7 \%)$ of the population are married. 4 respondents $(6.7 \%)$ of the population are divorced. 3 respondents $(5.0 \%)$ of the population are widowed.

Table 5: Number of years spent by respondents in First bank.

\begin{tabular}{|c|c|c|}
\hline Valid & Frequency & Percent \\
\hline 0 -2years & 18 & 30 \\
\hline 3-5years & 27 & 45 \\
\hline $6-11$ years & 10 & 16.7 \\
\hline Above 11years & 5 & 8.3 \\
\hline Total & 60 & 100 \\
\hline
\end{tabular}

Source: field survey, 2018.

Table 5 above shows the number of years spent by respondents in First bank. 18 respondents (30\%) of the population have spent between 0-2years in First bank. 27 respondents (45\%) of the population have spent between 3-5years in First bank. 10 respondents (16.7\%) of the population have spent between 611 years in First bank. 5 respondents $(8.3 \%)$ of the population have spent over 11years in First bank.

Table 6: Staff productivity influences performance of First bank.

\begin{tabular}{ll|l|}
\hline Valid & Frequency & Percent \\
\hline Strongly agree & 20 & 33.3 \\
\hline Agree & 28 & 46.7 \\
\hline Undecided & 10 & 16.7 \\
\hline Disagree & 2 & 3.3 \\
\hline Total & 60 & 100
\end{tabular}

Source: field survey, 2018. 
Table 6 above shows the responses of respondents that staff productivity influences performance of First bank. 20 respondents (33.3\%) of the population strongly agreed that staff productivity influences performance of First bank.28 respondents (46.7\%) of the population agreed that staff productivity influences performance of First bank. 10 respondents $(16.7 \%)$ of the population were undecided. 2 respondents $(3.3 \%)$ of the population disagreed that staff productivity influences performance of First bank.

Table 7: responses of respondents that staff productivity in First bank is high.

\begin{tabular}{lll|}
\hline Valid & Frequency & Percent \\
\hline Strong agree & 35 & 58.3 \\
\hline Agree & 20 & 33.3 \\
\hline Disagree & 3 & 5 \\
\hline Strongly agree & 2 & 3.3 \\
\hline Total & 60 & 100
\end{tabular}

Source: field survey, 2018.

Table 7 above shows the responses of respondents that staff productivity in First bank is high.35 respondents $(58.3 \%)$ of the population strongly agreed that staff productivity in First Bank plc is high. 20 respondents $(33.3 \%)$ of the population agreed that staff productivity in First Bank plc is high.

3 respondents $(5.0 \%)$ of the population disagreed that staff productivity in First bank is high.

2 respondents $(3.3 \%)$ of the population strongly disagreed that staff productivity in First Bank plc is high.

Table 8: Responses of respondents that change is acceptable in First Bank plc.

\begin{tabular}{lll|}
\hline Valid & Frequency & Percent \\
\hline Strongly agree & 32 & 53.3 \\
\hline Agree & 15 & 25 \\
\hline Undecided & 5 & 8.3 \\
\hline Disagree & 5 & 8.3 \\
\hline Strongly disagree & 3 & 5 \\
\hline Total & 60 & 100
\end{tabular}

Source: field survey, 2018.

Table 8 above shows the responses of respondents that change is acceptable in First Bank plc. 32 respondents $(53.3 \%)$ of the population strongly agreed that change is acceptable in First Bank plc. 15 respondents $(25 \%)$ of the population agreed that change is acceptable in First Bank plc.

5 respondents $(8.3 \%)$ of the population were undecided.

5 respondents $(8.3 \%)$ of the population disagreed that change is acceptable in First Bank Plc.

3 respondents $(5 \%)$ of the population strongly disagreed that change is acceptable in First Bank plc. 
Table 9: Respondents that the impact of change on staff productivity in First Bank plc is high.

\begin{tabular}{|l|l|l|}
\hline Valid & Frequency & Percent \\
\hline Strongly agree & 35 & 58.3 \\
\hline Agree & 15 & 25 \\
\hline Undecided & 5 & 8.3 \\
\hline Disagree & 3 & 5 \\
\hline Strongly disagree & 2 & 3.3 \\
\hline Total & 60 & 100 \\
\hline
\end{tabular}

Source: field survey, 2018.

Table 9 above shows the responses of respondents that the impact of change on staff productivity in First Bank plc is high. 35 respondents $(58.3 \%)$ of the population strongly agreed that the impact of change on staff productivity in First Bank plc is high. 15 respondents (25\%) of the population agreed that the impact of change on staff productivity in union bank is high. 5 respondents $(8.3 \%)$ of the population were undecided.

3 respondents $(5 \%)$ of the population disagreed that the impact of change on staff productivity in union bank is high. 2 respondents (3.3) of the population strongly disagreed that the impact of change on staff productivity in First Bank plc is high.

\subsection{Research Hypothesis Hypothesis I}

H0: Staff productivity in First Bank plc is low.

H1: Staff productivity in First Bank plc is high. Level of significance: 0.05

Decision Rule: reject the null hypothesis if the p-value is less than the level of significance, accept the null hypothesis if otherwise.

\section{Table 10 Test Statistics}

\begin{tabular}{|ll|}
\hline & Staff productivity in first bank is high \\
\hline Chi-Square & $49.000 a$ \\
\hline Df & 4 \\
\hline Asymp. Sig. & .000 \\
\hline
\end{tabular}

a. 0 cells $(.0 \%)$ have expected frequencies less than 5 . The minimum expected cell frequency is 12.0 .

Conclusion based on the decision rule:

Since the p-value $(0.000)$ is less than the level of significance, we reject the null hypothesis and conclude that Staff productivity in First Bank plc is high.

\section{Hypothesis II}

HO: change is not acceptable in First Bank plc. H1: change is acceptable in First Bank plc. Level of significance: 0.05

Decision Rule: reject the null hypothesis if the p-value is less than the level of significance, accept the null hypothesis if otherwise. 
Table 11:

\begin{tabular}{|l|l|}
\hline & Change is acceptable in first bank \\
\hline Chi-Square & $49.000 \mathrm{a}$ \\
\hline Df & 4 \\
\hline Asymp. Sig. & .000 \\
\hline
\end{tabular}

a. 0 cells $(.0 \%)$ have expected frequencies less than 5 . The minimum expected cell frequency is 12.0 .

Conclusion based on the decision rule:

Since the p-value (0.000) is less than the level of significance, we reject the null hypothesis and conclude that change is acceptable in First Bank plc.

Hypothesis III

$\mathrm{HO}$ : the impact of change on staff productivity in First Bank plc is negative. $\mathrm{H} 1$ : the impact of change on staff productivity in First Bank plc is positive.

Level of significance: 0.05

Decision Rule: reject the null hypothesis if the p-value is less than the level of significance, accept the null hypothesis if otherwise.

\section{Table 12}

\begin{tabular}{|l|l|}
\hline & The impact of change on staff productivity in first bank is positive \\
\hline Chi-Square & $49.000 \mathrm{a}$ \\
\hline Df & 4 \\
\hline Asymp. Sig. & .000 \\
\hline
\end{tabular}

0 cells $(.0 \%)$ have expected frequencies less than 5 . The minimum expected cell frequency is 12.0 .

Conclusion based on the decision rule:

Since the p-value (0.000) is less than the level of significance, we reject the null hypothesis and conclude that the impact of change on staff productivity in First Bank plc is positive.

\section{SUMMARY OF FINDINGS AND CONCLUSION}

Findings from the study revealed that staff productivity influences performance of First bank. Staff productivity in First Bank plc is high and Change is acceptable in First Bank plc.

\section{CONCLUSION}

This research evaluates organizational change and its impact on staff productivity using First Bank of Nigeria PLC Gbagada as a case study. It elucidates the concept of organizational change as an inevitable organizational process that is required to modify operations and organizational process. The research proffers an analysis of the concept of productivity and seeks to determine the impact of organizational change on staff productivity. Findings from the research showed that there are problems associated with ever constant changes in organizations and this impacts on productivity of staff Statistical analysis of gathered data also showed that staff productivity influences performance of the case study organization and that change is generally acceptable in First Bank plc. Future research can examine other parameters that influence staff productivity and change using other case studies. 


\section{REFERENCES}

1. Abramovitz, M (May 1956). "Resource and Output Trends in the United States since 1870" (PDF). American Economic Review (NATIONAL BUREAU OF ECONOMIC RESEARCH) 46 (2): 5-23.

2. Bechler, J.G (1984). "The Productivity Management Process". American Productivity Center.

3. Courbois, R.; Temple, P. (1975). La methode des "Comptes de surplus" etses applications macroeconomies. 160 des Collect, INSEE, Serie C (35). p. 100.

4. Craig, C.; Harris, R. (1973). "Total Productivity Measurement at the Firm Level". Sloan Management Review (Spring 1973): 13-28. Cite uses deprecated parameter |coauthors= (help)

5. Davis, H.S. (1955). Productivity Accounting. University of Pennsylvania. Freeman, R. (2008). Labor productivity indicators (PDF). OECD.

6. Action, G. E. (2000).Nikandrou, I; Papalexandris, N; Bourantas, D. Employee Relations, 22 (4), 334-355.

7. Aryee, S., Chen, Z. H., \&Budhwar, P. S. (2004). Exchange fairness and employee performance: An examination of the

8. relationship between organizational politics and procedural justice. Organizational Behavior and Human Decision Processes, 94 (1), 1-14.

9. Attia, A. M., Honeycutt, E. D., \&Attia, M. M. (2002). The difficulties of evaluating sales training. Industrial Marketing Management. 31 (3), 253-259.

10. Batool, B. F. (2013). An Empirical Study on Effect of Transformational Leadership. IOSR Journal of Business and Management (IOSR-JBM) , 38-44.

11. Bharathi, K. G. (2010). The Intellectual Capital Performance of Banking Sector in Pakistan. Pak. J. Commer. Soc. Sci, 4 (1), 84-99.

12. Brehm, J. (1972). Responses to loss of freedom: A theory of psychological reactance. General Learning Press. Champathes, M. R. (2006). Coaching for performance improvement:

13. The coach model. Development and Learning in Organizations. 20 (2), 17-18.

14. Genesca, G.E.; Grifell, T. E. (1992). "Profits and Total Factor Productivity: A Comparative Analysis". Omega. The International Journal of Management Science 20 (5/6): 553-568. doi:10.1016/0305- 0483(92)90002-O. Cite uses deprecated parameter |coauthors $=($ help)

15. Gollop, F.M. (1979). "Accounting for Intermediate Input: The Link Between Sectoral and Aggregate Measures of Productivity Growth". Measurement and Interpretation of Productivity (National Academy of Sciences).

16. Hulten, C.R. (January 2000). "TOTAL FACTOR PRODUCTIVITY: A SHORT BIOGRAPHY" (PDF).NATIONAL BUREAU OF ECONOMIC RESEARCH.doi:10.3386/w7471.

17. Hulten, C.R. (September 2009). "GROWTH ACCOUNTING" (PDF).NATIONAL BUREAU OF ECONOMIC RESEARCH.doi:10.3386/w15341.

18. Jorgenson, D.W.; Griliches, Z. (1967). "The Explanation of Productivity Change". Review of Economic Studies 